\title{
Kewajiban Pemberian Jasa Hukum Secara Cuma-Cuma Oleh Notaris Pada Orang Tidak Mampu
}

\section{Claudia Verena Maudy Sridana ${ }^{1}$ I Ketut Westra ${ }^{2}$}

1Program Studi Magister (S2) Kenotariatan, Fakutas Hukum Universitas Udayana, E-mail: claudiasridana@gmail.com

2Fakultas Hukum Universitas Udayana, E-mail: ketutwestrafh@gmail.com

\begin{tabular}{l}
\hline Info Artikel \\
\hline Masuk: 10 Juli 2020 \\
Diterima :16 Juli 2020 \\
Terbit: 15 Desember 2020 \\
Keywords: \\
Obligation; Legal Services; \\
Notary; People Can Not Afford \\
\\
\\
\\
Cridana, E-mail: \\
claudiasridana@gmail.com \\
DOI: \\
Claresponding Author: \\
Kata kunci: \\
Kewajiban; Jasa Hukum \\
Notaris; Orang TidakMampu \\
Corro.v05.i03.p02 \\
\end{tabular}

\begin{abstract}
As a public official who works as a notary public has the authority to be able to make an authentic deed. As a notary in carrying out his commitment to make an authentic deed, the Notary gets approval to provide his services for free or voluntarily to people who are not capable in the financial field. How can you ask for legal assistance by a notary in the free notary area for people who can't afford it? Problems related to legal notifications to notaries who refuse to provide legal assistance in the field of notary to those who are unable? The purpose of the discussion is to analyze and discuss the request for legal assistance by a notary in the notary sector not providing legal assistance in the notary sector for people who cannot afford. This research uses empirical legal research methods, primary data and secondary data obtained were analyzed qualitatively and arranged systematically, which was collected by literature study and interview techniques. The conclusion of this research is the notary in providing his services without collecting honorariums is not only given to people who can not afford it, but notaries can provide free services to those who want to make a foundation or activities in the social, social and dialogue. The legal consequences of notaries who are reluctant to provide legal assistance to people who are not in accordance with the provisions of the sanctions provided for in Article 37 paragraph (2) of the UUJN are also in accordance with the provisions in the Code of Ethics I.N.I.

\footnotetext{
Abstrak

Sebagai pejabat umum seorang yang berprofesi sebagai notaris mempunyai kewenangan untuk dapat membuat akta autentik. Sebagai notaris dalam melakukan kewenangannya membuat akta autentik, Notaris diwajibkan untuk memberikan jasanya secara cuma-cuma atau secara sukarela terhadap orang yang tidak berkemampuan dalam bidang finansial. Pada penulisan ini terdapat dua permasalahan mengenai Bagaimana penerapan pemberian bantuan hukum olehnotaris di bidang kenotariataan secara cuma-cuma terhadap orang yang tidak mampu? Permasalahan yang selanjutnya mengenai apa akibat hukum
} terhadap notaris yang menolak memberikan bantuan hukum di
\end{abstract}




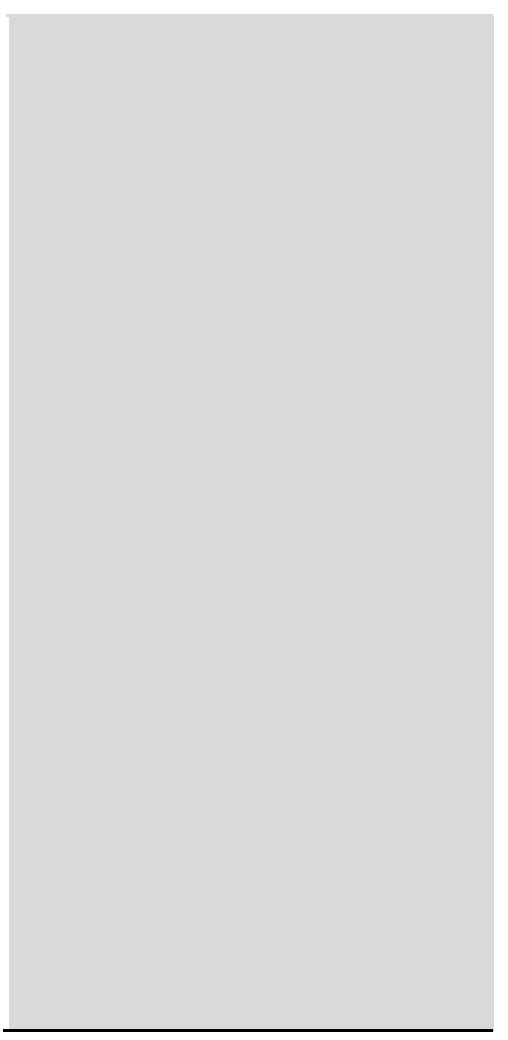

bidang kenotariatan kepada orang yang tidak mampu? Tujuan dari penulisan untuk menganalisis dan memahami permasalahan mengenai penerapan pemberian bantuan hukum oleh notaris dibidang kenotariatan secara cuma-cuma dan akibat hukum terhadap notaris yang tidakmemberikan bantuan hukum dibidang kenotariatan bagi orang yang tidak mampu. Penelitian ini mengguanakan Metode penelitian hukum empiris, data primer dan data sekunder yang diperoleh dianalisa secara kualitatif dan disusun secara sistematis, yang dikumpulkan dengan teknik studi kepustakaan dan wawancara. Kesimpulan dari penelitian ini adalah notaris dalam memberikan jasanya tanpa memungut honorarium tidak hanya diberikan kepada orang yang tidak mampu saja, tetapi notaris dapat memberikan jasa secara cuma-cuma kepada para pihak yang ingin mendirikan yayasan atau kegiatan-kegiatan dibidang sosial, kemanusiaan dan keagamaan. Akibat hukum terhadap notaris yang enggan memberikan bantuan jasa bantuan hukum kepada orang yang tidak mampu disesuaikan pada ketentuan sanksi yang ada pada ketentuan Pasal 37 ayat (2) UUJN juga sesuai ketentuan dalam Kode Etik I.N.I.

\section{Pendahuluan}

Sebagai salah satu profesi yang memiliki peran penting pada bidang hukum notaris diberikan wewenang dalam membuat suatu akta autentik dan sudah diaturkan di dalam ketentuan peraturan perundang-undangan. ${ }^{1}$ Profesi seorang notaris berperan untuk memberi bantuan kepada masyarakat apabila melakukan suatu tindakantindakan hukum. Adanya profesi notaris berasal dari adanya interaksi diantara masyarakat dan berkembang di dalam masyarakat. Berdasarkan Undang-Undang Republik Indonesia Nomor 2 Tahun 2014 Tentang Perubahan Atas Undang-Undang Nomor 30 Tahun 2004 Tentang Jabatan Notaris selanjutnya disebut UUJN, seorang notaris merupakan pejabat umum yang memiliki wewenang dalam membikin suatu akta autentik serta mempunyai wewenang-wewenang lain yang telah ditentukan pada UUJN maupun yang telah ditetapkan pada peraturan perundang-undangan lain. Berprofesi sebagai Notaris memiliki wewenang melaksanakan sebagian tugas dari kekusaaan negara dalam akta autentik yang berupa alat bukti tertulis pada bidang hukum keperdataan. Pada pembuatan akta autentik, notaris membuatnya dengan memuat semua perbuatan yang dilakukan oleh semua pihak tersebut dalam hal ini yaitu perbuatan hukum apa yang diperbuat, lalu disaksikan notaris dan tak luput juga kehadiran seorang saksi. Akta autentik yang dihasilkan nanti diharapkan dapat berguna dan dapat dipertanggunng jawabkan sehingga bisa memberi perlindungan hukum teruntuk semua pihaknya yang terlibat pada perjanjian tersebut.

${ }^{1}$ Kurniawan, I. W. A. (2018). Tanggung Jawab Notaris Atas Akta yang Tidak Dibacakan Dihadapan Para Penghadap. Acta Comitas: Jurnal Hukum Kenotariatan, 3(3), 489-499. 
Akta autentik yang dibuat Notaris mempuyai kekuatan hukum sebagai alat bukti yang kuat dan secara penuh memiliki peran yang penting pada semua hubungan hukum di dalam masyarakat. Dengan adanya akta autentik inilah yang akan menentukan dengan jelas bagaimana hak dan kewajian dari setiap pihak, yang nantinya akan memberi jaminan kepastian hukum, dan dapat diharapkan terhindar dari adanya sengketa untuk kedepannya. Maka akta autentik yang dihasilkan oleh seorang notaris memiliki suatu kekuatan bukti yang kuat dan penuh. ${ }^{2}$ Pada sebuah akta autentik memiliki pembuktian yang kuat dan penuh untuk para pihak, bila nantinya terjadi persengketaan, salah satu pihak dapat mengajukan keberatan dan dapat menjadi alat bukti dalam persidangan. Sebagai seorang Notaris selain berperan dalam permasalahan secara hukum notaris perlu untuk ikut berperan aktif didalam membangun hukum nasional. Maka dari hal tersebut seorang notaris pun patut sewaktu-waktu megikuti bagaimana perkembangan hukum nasional agar seorang notaris dapat mengimplementasikannya ke dalam pekerjaannya dengan professional dan sepadan. Menyandang jabatan sebagai seorang Notaris dianggap memiliki profesi yang terhormat, dikarenakan notaris memiliki peran yang penting bagi masyarakat.

Sebagai seorang notaris untuk dapat menjalankan tugas ia harus berped oman dengan peraturan-peraturan yang ada yaitu kode etik yang sudah ditentukan oleh Ikatan Notaris Indonesia. Seseorang dalam berprofesi memiliki etika, yang dimana hal tersebut merupakan etika moral yang dibentuk untuk baik berjalannya profesi sebagai notaris. Menurut Abdul Ghofur persyaratan dalam menyeimbangkan, dalam menyelaraskan, dan menyerasikan sesuai dengan Pancasila yang merupakan dasar dalam menerapkan berbagai hal dalam mengetahui bagian kepentingan individu, masyarakat, negara, dan kepentingan organisasi profesi. ${ }^{3}$ Menyeimbangkan kepentingan ini dilakukan untuk masyarakat yang mampu dalam finansial dan bagi yang tidak berkemampuan secara finansial dalam memberi honorarium kepada notaris atas jasanya. Sebagai Notaris dipaksa memiliki integritas agar dapat melaksanakan jabatannya sesuai dengan kewenangannya, melaksnakan pekerjaannya yang berpedoman pada kode etik yang menjadi sumpahnya dan hal terpenting dari semua itu adalah komitmen Notaris untuk bertindak be honest, be responsible, be confident. Pekerjaan sebagai seorang notaris mengemban tugas dari pemerintah dimana dalam tugas ini mengakibatkan suatu akibat hukum, dan pekerjaan notaris mempunyai sebagian dari kekuasaan negara sehingga hasil dari akta tersebut memilki kekuatan yang autentik dan eksekutorial. Selain itu juga memiliki suatu kewajiban dalam menjalani profesinya dan terdapat larangan-larangan yang harus dipatuhi. Pada pasal 15 ayat (1) sampai dengan ayat (3) UUJN sebagai notaris memiliki kewenangan untuk melaksanakan jabatan juga tugasnya. Pada Pasal 16 UUJN mengenai kewajibannya sebagai notaris. 4

Adanya suatu kewajiban bagi seorang notaris, mengakibatkan adanya hak yang bisa dituntut dari adanya kewajiban itu. Apabila dihubungkan dengan kewajiban seorang

2 Purwaningsih, E. (2011). Penegakan Hukum Jabatan Notaris dalam Pembuatan Perjanjian Berdasarkan Pancasila dalam Rangka Kepastian Hukum, Adil: Jurnal Hukum, 2(3), 323-336.

3 Abdul Ghofur Anshori. (2009). Lembaga Kenotariatan Indonesia (Perspektif Hukum dan Etika). UII Press. Yogyakarta. h. 31.

${ }^{4}$ Diana, P. V. P., Mertha, I. K., \& Artha, I. G. (2015). Pertanggung Jawaban Notaris Dalam Pembuatan Akta Berdasarkan Pemalsuan Surat Oleh Para Pihak, Acta Comitas: Jurnal Hukum Kenotariatn, 161-172.h. 6. 
notaris, untuk masyarakat datang kepada notaris tersebut dapat menuntut kewajiban notarisnya. Pada prakteknya, sering sekali ada notaris yang lebih mengutamakan material dibandingkan dengan sisi sosialnya. Bila dilihat lagi, seorang notaris memiliki kewajiban dan telah ditentukan pada peraturan perundang-undangan untuk menjaga idealisme dari seorang pejabat umum, tetapi seorang notaris juga mempunyai kehidupan yang harus terpenuhi baik secara materialisme, hal inilah yang terkadang membuat beberapa notaris melakukan hal-hal yang melanggar peraturan yang ada, notaris tersebut mengabaikan hal pokok utamanya yaitu sebagai pejabat umum yang memberi pelayanan untuk masyarakat. Kerap kali profesi notaris ini sering diartikan sebagai profesi yang dapat menghasilkan uang banyak, hal ini dikarenakan kebanyakan orang yang datang dan membutuhkan jasa notaris ialah orang yang mempunyai uang dan memiliki kemampuan dalam membayar. Disinilah terkadang ada notaris yang nakal yang memanfaatkan keadaan ini, namun tak luput juga banyak notaris yang memang tulus melakukan profesinya dengan tetap memberi pelayanan sesuai dengan peraturan dan kewajibannya. Salah satunya ialah dengan memberikan pelayanan tanpa memungut biaya jasa atau memberikan jasa dengan semampu kliennya saja dapat membayar dengan seikhlasnya.

Notaris dalam menjalankan tugas, fungsi dan perannya, Notarispun memiliki hak atas honorarium, yang artinya apabila telah menggunakan jasa seorang notaris, pihak tersebut memiliki kewajiban dalam membayar kepentingan-kepentingannya yang berhubungan dengan perbuatan hukumnya termasuk pula dalam membayar honorarium atas jasa notaris, namun notaris juga memiliki kewajiban dalam memberikan bantuan dengan sukarela terhadap para pihak yang tidak memiliki kemampuan lebih dalam finansial untuk membayar honorarium dari jasa seorang notaris. Berpatutan pada ketentuan Pasal 36 ayat 2 UUJN, mengatur tentang ketentuan honorarium bagi seorang Notaris harus mendasarkan pada nilai ekonomis dan nilai sosiologis dari setiap akta yag telah dibuat, pada peraturan tersebut ditujukan supaya adanya standard tarif dalam mematok tarif dari honorarium atas jasanya. Profesi ini mempunyai hak dalam menentukan honorarium atas nilai ekonomisnya sesuai dengan pertimbangan sendiri, tetapi tetap berpatokan terhadap batas-batas maksimal dari ketentuan yang ada. Untuk dapat menilai honorarium dan mempertimbangkannya penetapan honorarium bergantung dengan nilai secara ekonomi dan sosial yang muncul dengan timbulnya suatu transaksi dalam suatu perbuatan hukum yang dilakukan oleh pihak-pihak. Sebagai pejabat publik, notaris berperan sebagai pemberi pelayanan untuk masyarakat dalam hal perbuatan-perbuatan hukum, misal melayani pembuatan akta atau mengurus dokumen-dokumen yang legal berhubungan dengan perbuatan hukum tersebut. Berkaitan dengan memberikan jasanya itu, maka seorang notaris berhak dalam pemberian honorarium. ${ }^{5}$ Tetapi bila dilihat pada peraturan Pasal 37 Ayat (1) UUJN, haruslah pula bagi notaris untuk memenuhi kewajiban dalam memberi jasa bantuan dengan sukarela dalam bidang kenotariatan. Memberikan bantuan dengan sukarela ini dalam pengertian bahwa notaris membebaskan honor yang semestinya diberikan oleh masyarakat atau klien sebagai imbalan jasa Notaris.

${ }^{5}$ Buko, S. H. (2017). Analisis Yuridis Tentang Kewajiban Notaris Dalam Memberikan Jasanya Kepada Masyarakat Yang Tidak Mampu BerdasarkanUU No. 2 Tahun 2014. LEX PRIVATUM, $5(1)$. 
Mengenai ketidakmampuan penghadap untuk membayar honorarium, seorang notaris memiliki kewajiban dalam memberikan perlakuan hukum yang adil, dikarenakan notaris dalam membuat akta dan hasilnyapun tidak akan beda bagi masayrakat yang mampu dalam membayar maupun bagi pihak yang tidak memiliki kemampuan dalam membayar honorarium atas jasa notaris tersebut. Untuk meningkatkan pembangunan maka profesi seorang notaris sangat dibutuhkan, maka dari itu pada ketentuan Pasal 37 ayat (1) UUJN menentukan dimana untuk dapat melaksanakan profesinya seorang notaris bisa memberi perlindungan juga terjaminnya suatu bentuk kepastian hukum untuk semua pihak dan masyarakat tanpa melihat dari segi ekonomis atau kemampuan dari orang tersebut. Peraturan yang ada pada Pasal 37 ayat (2) UUJN merupakan suatu dasar dalam melaksanakan pekerjaannya sebagai notaris dalam memberikan jasanya dibidang hukum kenotariatan dengan cuma-cuma atau secara sukarela.

Penelitian terdahulu yang berkaitan dengan penelitian ini, dilakukan oleh Diah Ayu Puspita Sari pada tahun 2016, adapun makna dari pasal 37 ayat (1) UUJN terhadap notaris yang memberikan jasa secara cuma-cuma kepada orang tidak mampu yakni mengandung nilai rohani, ekonomis, dan sosiologis. Pemberian jasa hukum di bidang kenotariatan yang dapat diberikan notaris yaitu berupa pengurangan honorarium notaris atas jasanya membuatkan suatu akta namun semua tidak semestinya hanya pengurangan honorarium saja tetapi beberapa notaris karena jiwa sosialnya ada yang memberikan jasanya secara cuma-cuma terhadap orang tidak mampu ini. ${ }^{6}$ Perihal tersebut meneguhkan bahwa seorang noatris memiliki suatu kewajiban dalam mendahulukan pengabdian bagi masyarakat dan bagi kepentingan negara, dalam melaksanakan suatu kewajibannya juga harus berpedoman pada peraturan di UUJN ada peraturan dalam kode etik profesi notaris, seperti contohnya bagi masyarakat yang tidak mampu, akan dibebaskan dalam pembayaran honorarium atas jasa pembuatan akta ataupun jasa-jasa hukum lainnya yang berhubungan dengan pembuatan suatu akta. Adapun pemasalahan dalam penulisan ini yaitu mengenai bagaimana penerapan pemberian bantuan hukum oleh notaris di bidang kenotariataan dengan sukarela dan cuma-cuma terhadap orang yang tidak mampu dan apa akibat hukum terhadap notaris yang tidak memberikan bantuan hukum di bidang kenotariatan kepada orang yang tidak mampu.

Tujuan penulisan ditujukan untuk menganalisis dan memahami permasalahan mengenai penerapan dalam memberikan bantuan hukum oleh notaris dibidang kenotariatan dengan cuma-cuma dan akibat hukum bagi notaris yang tidak memberikan bantuan hukum dibidang kenotariatan bagi orang yang tidak mampu dalam finansialnya.

\footnotetext{
${ }^{6}$ Sari, D. A.P. (2016). Makna Pemberian Jas a Hukum Secara Cuma-cuma Oleh Notaris PadaOrang Tidak Mampu Terkait Sanksi Yang Diberikan Oleh Undang-undang Jika Tidak Dipenuhi (Analisis Pasal 37 Ayat (1) Dan (2) Undang-undang Jabatan Notaris No. 2 Tahun 2014). Kumpulan Jurnal Mahasiswa Fakultas Hukum.
} 


\section{Metode Penelitian}

Metode penelitian hukum ialah model yang tersistematis dalam mengadakan sebuah penelitian. Pendapat dari Soerjono Soekanto memberi pengertian penelitian hukum ialah rangkaian suatu kegiatan ilmiah, sesuai dengan metode, melakukan penataan, juga merupakan ide-ide dalam suatu pemikiran, yang dimaksudkan dapat untuk dipelajari dan dipahami gejala-gejala hukum ada dilapangan, lalu menganalisis permasalahan yang ada. ${ }^{7}$ Pada penelitian ini memakai jenis penelitian yuridis empiris dimana dalam melakukan penelitian tersebut tentang memberlakukan ataupun mengimplementasikan ketentuan-ketentuan hukum dengan aksi di setiap peristiwaperistiwa hukum yang terjadi dimasyarakat tersebut. Pada penelitian mempergunakan jenis pendekatan, pendekatan fakta (fact approach), pendekatan perundang-undangan (statue approach) juga pendekatan konseptual (conceptual approach). Data primer berdasarkan perolehan sumber pertama lalu untuk data sekunder berasal dari buku kepustakaan, dokumen yang berhubungan dengan permasalahan, dokumen-dokumen tersebut seperti bahan hukum primer yaitu Kitab Undang-Undang Hukum Perdata, Undang-Undang Nomor 2 Tahun 2014 tentang Perubahan Atas Undang-Undang Nomor 30 Tahun 2004 tentang Jabatan Notaris, dan Kode Etik Notaris, untuk bahan hukum sekundernya yaitu berupa buku-buku, berupa karya ilmiah, hasi-hasil penelitian yang ada sebelumnya, hasil penelitian-penelitian dari praktisi hukum yang sejenis dan terkait dengan penelitian yang akan dibahas. Pada penelitian memakai teknik studi kepustakaan mengenai bahan-bahan dan data hukum yang berhubungan serta menggunakan teknik wawancara (interview) langsung dengan narasumber terkait yang mempunyai kewenangan terhadap permasalahan untuk mendapati jawaban yang relevan dengan permasalahan. ${ }^{8}$ Setelah itu mengumpulkan data-data dan menganalisisnya dengan teknik analisis data kualitatif agar mendapatkan suatu kesimpulan secara tepat dan sistematis. Untuk seluruh data yang didapatkan, data primer ataupun data sekunder semuanya akan disusun dengan sistematis, menggolongkannya kedalam tema dan pola, mengkatagorikan, mengklarifkasikan, setalah itu dikumpulan dengan data-data lainnya, dan melakukan interprestasi agar dapat mengerti dan memahami data dan situasi sosial yang terjadi dimasyarakat, selanjutnya menafsirkan seluruh data yang telah dikumpulkan.

\section{Hasil Dan Pembahasan}

\subsection{Penerapan Pemberian Bantuan Hukum Oleh Notaris Di Bidang Kenotariataan Secara Cuma-Cuma Terhadap Orang Yang Tidak Mampu}

Notaris sebagai pejabat umum dalam melakukan tugasnya memiliki kewajiban dalam memberi pelayanan yang terbaik bagi masyarakat baik bagi orang yang memiliki kemampuan ataupun bagi orang yang kurang mampu secara finansial. Untuk dapat memberi kepastian hukum, adanya profesi notaris ini dangat dibutuhkan oleh setiap warga negara dalam hal membuat akta autenthik sehingga bisa memberikan hukum yang pasti dan keadilan hukum teruntuk yang membuat

\footnotetext{
7 Soerjono Soekanto. (2014). Pengantar Penelitian Hukum, cetakan Ketiga. UIPress. Jakarta. h. 42. ${ }^{8}$ Gitayani, L. P.C. (2018). Penerapan Etika Profesi oleh Notaris dalam Memberikan Pelayanan Jasa Kepada Klien. Acta Comitas: Jurnal Hukum Kenotariatan, 3(3), 426-435.
} 
suatu perjanjian. ${ }^{9}$ Notaris dituntut untuk bisa memberi penyuluhan hukum bagi para pihak yang datang kepadanya agar bias memperoleh kesadaran hukum yang penuh dan setiap orang mampu memahami hal-hal yang berupa hal dan kewajibannya sebagai warga negara. Menurut pendapat Tobing yang dikutip oleh Widyaharma, beliau menyampaikan bahwa langkah untuk meningkatkan profesionalisme para notais tidak saja sebatas pada mengetahui kewajiban dan posisi sebagai seorang notaris, namun juga perlu mengetahui apa yang menjadi keinginan atau kehendak dari masyarakat yang akan dilayaninya. ${ }^{10}$ Sesuai dengan pendapat tersebut memperjelas peran notaris sebagai pejabat umum yang sudah diberi keyakinan untuk menjalankan tugas dari negara untuk bisa mencukupi apa yang dibutuhkan oleh masyarakat. A pabila surat keputusan pengangkatan seorang notaris telah disetujui, notaris telah dilantik secara yuridis formal, disaat itu juga telah memuat segala janji seorang notaris dalam melaksanakan profesinya dengan baik, sesuai dengan ketentuan bahwa notaris berdomisili dan percaya akan hukum dari Tuhan yang Maha Esa. Dwi Suryahartati memberikan pendapatnya bahwa, "berprofesi sebagai seorang notaris tidak hanya mengenai untung dan kerugian namun juga berkaitan dengan tanggung jawab secara sosial, yang mewajibkan notaris dapat memberikan jasanya dibidang hukum khususnya kenotariatan dengan sukarela kepada masyarakat yang membutuhkan dan tidak berkemampuan secara finansial untuk membayar honorarium, hal inilah yang ditegaskan dalam UUJN. ${ }^{11}$

Kewajiban dalam suatu profesi mutlak dilakukan oleh orang yang memiliki kewajiban tersebut, jika dilanggar atau tidak melakukan kewajiban, maka akan diberlakukan sanksi-sanksi yang telah diatur. Beruhubungan dengan profesi sebagai notaris, kewajiban dan kuatnya pembuktian sebuah akta yang dihasilkan oleh seorang notaris, lalu menurut Habib Adjie memberikan pendapatnya dengan menyimpulkan :12

1. Jabatan notaris memiliki tugas untuk merumuskan keinginan dari pihakpihak ataupun segala perbuatan-perbuatan yang akan dilakukan pihakpihak tersebut yang akan di tuangkan kedalam akta autentik, yang disesuaikan dengan segala peraturan yang ada dan masih berlaku.

2. Sebagai akta yang telah dibuat oleh notaris yaitu akta, mempunyai kekuatan pembuktian sempurna dimata hukum, sehingga akta autentik tidaklah mesti dibuktikan kembali, dan bila nantinya ada salah seorang pihak yang menyampaikan bahwa akta itu salah atau tidak benar kebenarannya, selanjutnya akan diperlukan pembuktian atau pernyataan yang sesuai dengan ketentuan yang berlaku.

\footnotetext{
${ }_{9}$ Dirgantara, P. Tanggung Jawab Saksi Pengenal Terhadap Keterangan yang Diberikan dalam Pembuatan Akta Autentik, Acta Comitas: JurnalHukum Kenotariatan, 4(2), 187-197. ${ }^{10}$ Ignatius Ridwan Widyadharma. (2009). Kenotariatan Indonesia. UIIPress. Yogyakarta.h. 106. ${ }^{11}$ Dwi Suryahartati, Peran Perguruan Tinggi Dalam PraktikTerkini Profesi Notaris yang Lihur dan Bermartabat, http:/ / webunja.unja.ac.id/artikel / 88-peranan-perguruan-tinggi-dalam-praktikterkini-profesi-notaris-yang-luhur-dan- bermartabat, Diakses pada tanggal 17 Januari 2020. 12 Buko, S. H. Op.cit.h. 90.
} 
Terdapat pula keharusan seorang notaris untuk merahasiakan akta dan mempunyai kewajiban menjaga kerahasiaan terkait isi dari pembicaraan antar para pihak pada waktu sebelum dibuatnya akta tersebut. Notaris memiliki kewajiban dalam memberikan bantuan dengan sukarela terhadap masyarakat yang memerlukan atau membutuhkan jasa dari seorang notaris namun orang tersebut tidak memiliki kemampuan secara ekonomi, dalam artian tidaklah memiliki kemampuan dalam membayarkan biaya jasa dari notaris tersebut, dan ini sesuai dengan peraturan dalam Pasal 37 UUJN. Menolak dalam memberikan bantuan dapat saja dilakukan oleh seorang notaris, apabila dalam membuat akta tersebut memuat isi perjanjianperjanjian yang melanggar ketentuan-ketentuan umum atau kesusilaan, dan apabila tidak adanya saksi yang bisa diperkenalkan kepada notaris maupun tidak turut hadirnya pada pembuatan akta, maka notaris dapat menolak untuk membuatkan akta autentik. Jabatan sebagai seorang pejabat umum memiliki fungsi atau tugas wilayah diranah pemerintahan maka dari itu notaris dituntut pula harus bersedia memberi pelayanan kepada semua masyarakat tanpa membeda-bedakannya. Notaris harus dapat memberikan jasa dibidang hukum untuk rakyat yang memang memerlukan jasa notaris, dapat memiliki arti yang luas yaitu seperti memberikan jasa hanya sebatas memuatkan suatu akta, melegalisasi akta-akta dibawah tangan, memberi layanan hukum teruntuk rakyat yang memerlukan jasanya, seperti halnya bila memberikan penyuluhan-penyuluhan tentang hukum khususnya dibidang kenotariatan maupun penyuluhan hukum yang menyangkut dengan permasalahan yang dihadapi orang tersebut. Dapat juga notaris memberikan informasi-informasi mengenai persyaratan-persayaratan yang harus dilakukan untuk membuat akta autentik tersebut. Pemberian informasi terkait hal tersebut tidak saja dilakukan oleh seorang notaris sendirian, namun diberlakukan juga bagi pegawai-pegawai yang bekerja pada notaris itu, mereka diwajibkan untuk dapat memberikan pelayanan sebaik mungkin dengan keramah-tamahannya dan turut juga memberikan informasi-informasi dalam melengkapi dokumen-dokumen yang diperlukan dalam membuat suatu akta autentik. Semua ini merupakan bagian dari berjalannya profesi jabatan notaris yang baik. Memberikan pelayanan-pelayanan hukum ini juga tetap harus berpedoman dengan segala peraturan yang ada dan sesuai dengan UUJN maupun peraturan dalam kode etik seorang notaris. Hal-hal tersebut wajiblah dilakukan supaya dalam menjalaninya profesi jabatan seorang notaris dimata masyarakat tetap memilki nilai derajat dan bermartabat.

Notaris bila memberikan pelayanannya tetap berpedoman pada peraturan UndangUndang Jabatan Notaris maupun pada ketentuan Kode Etik Notaris, hal ini dimaksudkan supaya profesi sebagai pejabat umum tidak direndahkan dan masyarakat enggan untuk berbuat seenaknya karena secara tidak langsung profesi notaris dihormati. Berdasarkan hal tersebut, pelayanan dan mengenai proses dalam memberikan pelayanan yang baik dapat menunjang karir dari notaris tersebut. Apabila ditambah dengan notaris tersebut dapat memberikan pelayanan seiklasnya dengan tidak memungut imbalan atas jasanya di masyarakat yang tidak mampu ataupun kegiatan-kegiatan yang berhubungan dengan sosial sehingga bisa meningkatkan rasa percaya rakyat kepada notaris tersebut, dan mempunyai nilai lebih di masyarakat. Namun terdapat kekurangan mengenai peraturan apabila memberi jasa dengan sukarela terhadap masyarakat yang tidak mampu, yaitu tidak adanya pengaturan lebih lanjut terkait persayaratan apa yang harus dipenuhi dalam mendapatkan pelayanan tersebut. Pada peraturan Pasal 37 ayat (1) UUJN, 
dimaksudkan agar dapat untuk memberikan bantuan pada kenotariatan dengan ketentuan: "Notaris wajib memberikan bantuan hukum di bidang kenotariatan secara cuma-cuma kepada orang yang tidak mampu." Terdapat pula pengaturannya pada Pasal 3 ayat 7 Kode Etik Notaris menentukan "memberikan jasa pembuatan akta dan jasa kenotarisan lainnya untuk masyarakat yang tidak mampu tanpa memungut honorarium." Bantuan hukum dibidang kenotariatan dapat dilakukan dengan berdasarkan pula ketentuan pada Pasal 15 angka 2 huruf e UUJN, yaitu notaris memiliki wewenang dalam menyampaikan penyuluhanpenyuluhan hukum yang berhubungan pada kebutuhan dalam membuat akta tersebut pula dapat memberi penyuluhan hukum yang berhubungan dengan membuat akta.

Notaris dalam memberikan pengarahan tentang hukum pada saat pembuatan akta sangtlah dibutuhkan. Hal itu merupakan kewajiban dari seorang notaris pada saat pembuatan akta berlangsung. Pada saat memberikan informasi atau pengarahan tentang hukum bertujuan agar para pihaknya mengerti dan memahami, tindakantindakan apa yang akan dilakukan para pihaknya baik setelah atau sebelum pembuatan akta tersebut. Tujuan memberikan pengarahan secara hukum bagi notaris dimaksudkan agar dapat memberi pemahaman-pemahaman lebih mendalam terkait pembuatan akta. Sampai sekarang ada saja terjadi kesalah pahaman dimasyarakat terkait pembuatan akta. Penyuluhanhukum ini memiliki fungsi sebagai lengkah-langkah dalam mencegah, langkah dama korektif, sebagai langkah dari pemeliharaan, dan berfungsi sebagai suatu pengembangan dalam permasalahan yang terjadi. Untuk penjelasan penyuluhan hukum sebagai langkah pencegahan (preventif), yaitu dilakukan untuk dapat mencegah terjadinya atau timbul hak-hak yang bertentangan atau negatif sehingga bisa mengakibatkan kerugian bagi para pihak maupun bagi orang lain. Selanjutnya, disebut penyuluhan sebagai langkah yang korektif, yaitu memiliki fungsi untuk mengoreksi setiap atau sesuatu hal yang telah ada, jadi bila ada hal yang bertentangan atau melanggar ketentuan umum, dapat mencegah akibat maupun dapat meniadakan hal itu. Untuk yang ketiga, diharapkan sebagai langkah-langkah pemeliharaan (presevatif), yaitu dapat memberi suatu kemajuan dalam meningkatkan semangat agar mau untk berpartisipas dalam pembangunan hukum yang sesuai dengan kedudukan dn kemampuan para pihak. Terakhir fungsi adanya penyuluhan hukum untuk suatu pengembangan dengan memberi suatu masukan terhadap hal itu supaya masyarakat dapat bersikap lebih mandiri. ${ }^{13}$ Mengenai penjelasan tentang bagaimana ketentuan-ketentuan yang harus terpenuhi agar dapat pelayanan secara cuma-suma atau memberikan honorarium dengan seadanya untuk notaris tidak adanya peraturan yang jelas pada undang-undang yang berlaku khususnya dalam UUJN. Pada ketentuan Pasal 37 UUJN dimana pada ketentuan tersebut hanya menjelaskan mengenai kewajiban seorang notaris bila memberi jasa hukum dengan cuma-cuma pada orang yang tidak mampu, jadi bila menerapkan ketentuan itu untuk menjalaninya bergantung pada pribadi dari notaris tersebut, yang dipengaruhi oleh faktor kemanusian, penjelasan atau keterusterangan klien apabila tidak mampu, dan dari keyakinan notaris itu sendiri.

${ }^{13}$ Laurensius Arliman, S. (2013). Kewajiban Notaris Dalam Pemberian Penyuluhan Hukum Kepada Masyarakat Berdasarkan Undang-Undang Nomor 2 Tahun 2014 Tentang Perubahan Atas Undang-Undang Nomor 30 Tahun 2004 Tentang Jabatan Notaris. Jurnal Advokasi, 4(2). 
Pada saat melakukan tugasnya dan jabatann notaris walaupun dilantik dan diberhentikan jugaoleh pemerintah notaris tersebut tidak akan memperoleh upah atau gaji pensiunan daripemerintah melainkan pendapatan tersendiri dari pribadi notaris tersebut. Artinya bila notaris sedang melaksanakan tugasnya, ia akan memperoleh honorarium dari klien yang memerlukan jasa hukum darinya. ${ }^{14}$ Dalam memberikan jasanya tanpa memungut honorarium tidak hanya diberikan kepada oranga tau masyarakat yang tidak memiliki kemampuan secara finansial saja, tetapi notaris bisa juga memberikan jasa dengan sukarela kepada para pihak yang ingin mendirikan yayasan atau kegiatan-kegiatan dibidang sosial, kemanusiaan dan keagamaan. Berdasarkan ketentuan Pasal 36 ayat (2) menentukan "Besarnya honorarium yang diterima oleh notaris didasarkan pada nilai ekonomis dan nilai sosiologis dari setiap aktanya." Nilai sosiologis ditentukan berdasarkan fungsi sosial dari objek setiap akta yang dibuatnya dengan honorarium yang diterima...". Akta yang mempunyai fungsi sosial ini diperjelas dalam Penjelasan Atas UndangUndang Nomor 30 Tahun 2004 Tentang Jabatan Notaris, misalnya dalam pembuatan akta pendirian yayasan, akta tanah wakaf, akta pendirian tempat ibadah, akta pendirian sekola, ataupun akta pendirian lainnya yag bersifat sosial. Sesuai dengan wawancara dengan Bapak Notaris/PPAT I Gusti Ngurah Agung Diatmika, S.H., beliau menyampaikan bahwa pemberian jasa hukum dengan sukarela oleh notaris tidak saja diberikan untuk orang yang tidak memiliki kemampuan saja, namun dapat diberikan untuk kegiatan yayasan, kegiatankegiatan dibidang sosial, kemanusiaan, dan keagamaan. Kegiatan-kegiatan dibidang sosial, kemanusiaan, dan keagamaan ini dapat notaris buatkan, akta tanah wakaf, pembuatan akta yayasan, akta dalam mendirikan sekolah, dalam pembuatan akta untuk rumah ibadah, maupun akta lainnya yang berhubungan dengan tindakan sosial, sesuai nilai sosiologis notaris dapat memberikan jasa tanpa memungut honorarium atau memungut honorarium dengan biaya seikhlasnya maupun menguranginya dari jumlah yang semestinya. (hasil wawancara pada tanggal 27 November 2019)

Bila melakukan pengurangan pada honorarium notaris, dapat notaris berikan pada klien apabila klien tersebut tidak memiliki kemampuan dalam memberi upah honorarium notaris tersebut yang disesuaikan dengan jenis akta yang dibuat, notarispun akan menanyakan kesanggupan klien apakah dapat membayar honorarium notaris secara penuh. ${ }^{15}$ Jika dalam pendirian yayasan terdapat ada profit yang akan diperoleh, notaris dapat meminta honorarium atas jasanya. Hal ini balik lagi ke setiap pribadi masing- masing dari notaris tersebut, apakah notaris tersebut ingin memberikan jasa hukum dengan ikhlas terkait dengan pembuatan akta yang mempunyai fungsi sosial. Notaris akan memberikan atau mengurangi honorarium dari jasa notaris tersebut apabila klien tersebut mengakui bahwa tidak menyanggupi untuk membayarkan hal tersebut, selanjutnya notaris akan menanyakan terkait seberapa kesanggupan dari klien untuk dapat membayar

\footnotetext{
${ }^{14}$ Gultom, R. (2017). Penetapan Honorarium Atas Jasa Hukum Notaris. Jurnal. Universitas Hasanuddin.

15 Sari, D. A. P. (2016). Makna Pemberian Jasa HukumSecara Cuma-cuma Oleh Notaris Pada Orang Tidak Mampu TerkaitSanksi Yang Diberikan Oleh Undang-undang Jika Tidak Dipenuhi (Analisis Pasal 37 Ayat (1) Dan (2) Undang-undang Jabatan Notaris No. 2 Tahun 2014). Kumpulan JurnalMahasiswa Fakultas Hukum.
} 
honorarium notaris tersebut.16 Penerapan dalam memberi jasa hukum dengan sukarela terhadap orang yang tidak mampu apabila telah dilaksanakan, terdapat pembiayaan lainnya yang tetap wajib dibayarkan oleh orang yang tidak berkemampuan tersebut, hal ini juga dapat menjadi beban bagi Notaris. Maksud dari hal tersebut adanya pengenakan biaya pada Penerimaan Negara Bukan Pajak (PNBP), ketentuan ini sudah pasti atau ditentukan oleh pemerintah dalam hal bidang pertanahan ataupun pada bidang Kementrian Hukum dan Hak Asasi Manusia dimana pada prakteknya pembayaran-pembayaran tersebut tidak mengenal bagaimana keadaan ekonomi dari orang yang bersangkutan itu. Hal inilah yang menjadi kedilemaan bagi seorang notaris karena disatu sisi notaris diwajibkan untuk melayani orang yang tidak memiliki kemampuan lebih pada ekonominya dilain halnya ada pembayaran-pembayaran yang diwajibkan seperti Pendapatan Negara Bukan Pajak (PNBP) yang pembayaran tersebut ditujukan untuk Negara. ${ }^{17}$ Apabila Notaris juga harus membiayai segala yang ditimbulkan maka hal tersebut juga dapat membebani sang notaris dari segi ekonomi.

Terdapat faktor-faktor yang menjadi latar belakang dalam memberikan jasa hukum dengan sukarela oleh notaris yaitu:

1. Faktor kemanusiaan

Berdasarkan faktor kemanusiaan, dalam memberikan bantuan dengan cuma-cuma di bidang kenotariatan, notaris berlandaskan dengan adanya suatu dorongan terhadap moralitas seorang notaris dalam memberikan bantuan terhadap sesama, yang dimana klien tersebut memiliki kekurangan dalam finansial secara ekonomi dan meminta bantuan untuk dapat dibuatkan akta tanpa memberikan honorarium atau dengan tidak membayar honorarium dengan penuh kepada notaris tersebut. Situasi seperti ini dapat mencerminkan notaris yang mempunyai nilai intregitas moral yang tinggi dalam melaksanakan kewajibannya dengan professional sebagai notaris.

\section{Faktor kejujuran klien kepada notaris}

Faktor terus terang atau kejujuran dari seorang klien sangatlah diperlukan dalam memberikan jasa hukum dengan sukarela oleh seorang notaris. Dengan adanya suatu kejujuran dari pihak klien mengenai ketidak sanggupan klien dalam membayar honorarium atas jasa hukum notaris, dapat menggugah, menyentuh jiwa sosial dari notaris sehingga notaris dapat memberikan keringanan dan bantuan bagi klien tersebut.

3. Faktor keyakinan notaris terhadap para pihak yang menghadap.

Faktor keyakinan notaris dalam memberikan bantuan bagi orang tidak mampu didasarkan juga pada penilaian dari seorang notaris mengenai penampilan maupun jenis jasa hukum apa yang diinginkan orang terebut,

16 Ibid,

17 SN, H. R. (2017). Pelaksanaan Pelayanan Jasa Notaris Terhadap Orang Tidak Mampu.

Keadilan Progresif, 8(1). 
sehingga nantinya dari penilaian itu dapat memberikan suatu keputusan yang bijak dalam melayani masyarakat khususnya bagi rakyat yang tidak mampu.

Makna pada pemberian jasa hukum dengan sukarela oleh notaris terhadap masyarakat yang tidak memiliki kemampuan yang lebih, memiliki suatu pengertian dimana dalam memberikan jasa hukum tersebut dilatarbelakangi oleh moralitas dan intregitas seorang notaris, dan didukung pula dengan faktor-faktor ilmu pengetahuan mengenai peraturan yang terdapat di dalam UUJN, yaitu dengan melaksanakan kewajiban notaris dalam memberikan jasa hukum tanpa memungut biaya honorarium atas jasanya dengan sukarela terhadap msayarakat yang tidak mampu, hal ini dikarenakan dengan tidak adanya pengetahuan yang cukup mengenai kewajiban tersebut, maka kewajiban itu tidak dapat terlaksana dengan maksimal dalam menjalankan profesinya di masyarakat. Bapak Notaris/PPAT I Gusti Ngurah Agung Diatmika, S.H. menyampaikan bahwa, untuk dapat jadi seorang notaris secara professional, bermartabat, juga dipercaya masyarakat, haruslah menjadi notaris yang tidak berorientasi terhadap uang, tetapi lebih mempraktekan profesi untuk membantu masyarakat khususnya yang berkaitan dengan keperdataan, membantu antar sesama dengan hati nurani, karena apabila sudah menjalani profesi dengan hati nurani yang ikhlas untuk membantu sesama, masyarakat akan percaya dan mau datang lagi untuk melakukan segala perbuatan hukum keperdataan di kantor notaris tersebut. Notaris tersebut juga akan memperoleh kebahagian dan kesejahteraan hidup. (hasil wawancara pada tanggal 27 November 2019)

Dapat terlaksananya suatu kewajiban yang telah ditentukan pada Pasal 37 UUJN dan pada ketentuan pasal 3 ayat (7) kode etik notaris, menjadikan harkat dan martabat seorang notaris meningkat di masyarakat, dan dapat menambah kepercayaan dari masyarakat kepada notaris dalam membantu masyarakat kecil, dalam memberikan jasa hukum khususnya pada bidang kenotariatan. Kerja maksimal bagi notaris dalam menjalankan segala tugas dan kewajiban dalam menjabatnya akan pula meningkatkan intergritas notaris, sehingga notaris juga akan mendapatkan kesejahteraan dan kebahagiaan dalam hidup. Hal yang dapat menjadi tolak ukur kemanusiaan bagi notaris, dapat diartikan dengan melayani ataupun memperlakukan klien dengan baik, dengan tidak membeda-bedakan dalam memberikan pelayanan, tidak mendeskriminasikan pihak yang mampu maupun yang tidak mampu, dengan melayani memperlakukan klien dengan adil. Berdasarkan nilai kemanusiaan ini dapat menjadi landasan bagi seorang notaris agar tidak menyalahgunakan profesi jabatan, dan nilai kemanusiaan ini dapat menandakan notaris untuk selalu berlaku dan berbuat secara manusiawi, agar dapat menjalani profesinya secara professional.

\subsection{Akibat Hukum Terhadap Notaris yang Tidak Bersedia Memberikan Jasa Bantuan Hukum di Bidang Kenotariatan Kepada Orang yang Tidak Mampu}

Kewajiban tugas sebagai seorang notaris dalam menjalankan profesinya sesuai dengan peraturan-peraturan yang di tentukan dalam UUJN dan Kode Etik Notaris Indonesia dan peraturan perundang-undangan lainnya yang berlaku. Sehingga dalam melaksanakan tugas dan kewajiban jabatannya bisa terhindar dari 
pelanggaran yang sudah tertuang dalam ketentuan-ketentuan yang berkaitan. Pada dasarnya notaris mempunyai beban tanggungjawab atas perbuatannya tetapi tidak dapat diartikan segala kerugian yang timbul bagi pihak ketiga menjadi tanggungjawab notaris. Dalam hal ini hukum pun memberi batasan terhadap tanggungjawab seorang notaris. Hal ini dapat diartikan sebagai salah satu bentuk dalam memberikan perlindungan terhadap pejabat umum yang memberikan pelayanan. Dalam melaksanakan tugasnya notaris mempunyai wewenang sebagai pejabat umum, dalam melakukan tugas dan menjalani jabatannya, mempunyai wewenang dalam membuat akta autentik dan harus bertanggung jawab terhadap semua perbuatannya. Maka dari itu, apabila notaris tersebut menolak dalam memberikan jasa berupa bantuan hukum terhadap orang yang tidak memiliki kemampuan lebih secara finansial, dapat saja terjadi dan tidak bisa di paksakan karena kemampuan dari setiap notaris berbeda-beda. Terkait dengan pembayaran pada jasa notaris dapat saja tidak dikenakan tetapi pada pembiayaan lainnya yang memang diharuskan dikenakan kepada pihak tersebut seperti biaya pendaftaran fidusia dan lainnya, pihak yang tidak mampu tersebut tetap saja dikenakan biaya.

Bila seorang notaris tidak mau memberikan bantuan secara hukum kepada masyarakat yang tidak mampu, maka dapat dilihat terlebih dahulu apa penyebab terjadinya penolakan tersebut, seperti halnya apabila :18

a. Notaris tidak memahami perjanjian atau perbuatan hukum yang diinginkan pihak tersebut untuk dilakukan notaris;

b. Notaris menyadari bahwa perbuatan hukum yang diminta oleh klien ternyata melanggar ketentuan hukum yang sudah ada dan tidak sesuai, melanggar hukum;

c. Notaris tidak mempunyai kapasitas untuk melakukan pekerjaan yang diminta oleh klien; dan

d. Klien meminta sesuatu yang dimana hal tersebut diluar wewenang notaris yang bersangkutan.

Sesuai pada ketentuan Pasal 1 angka 15 Kode Etik Notaris, pelanggaran merupakan perbuatan atau tindakan yang dilakukan oleh anggota perkumpulan maupun orang lain yang memangku dan menjalankan jabatan notaris yang melanggar ketentuan-ketentuan dalam Kode Etik dan/atau disiplin organisasi. Selanjutnya penjelasan mengenai sanksi diatue dalam ketentuan Pasal 1 angka 18 Kode Etik Notaris, yaitu suatu hukuman yang dimaksudkan sebagai sarana, upaya dan sifat pemaksa ketaatan dan disiplin anggota Perkumpulan maupun oranglain yang memangku dan menjalankan jabatan notaris, dalam menegakkan kode etik dan disiplin organisasi. Dapat diartikan bahwa pelanggaran notaris yaitu dimana notaris tersebut tidak melaksanakan segala kewajibannya d an berbuat pelanggaran dan segala larangan yang telah ditentukan pada Kode Etik Notaris. Notaris mempunyai suatu bentuk tanggung jawab bagi pribadi dan publik, memiliki tanggung jawab terhadap dirinya sendiri dapat memiliki pengertian sebagai orang berprofesional dalam melakukan pekerjaan dikarenakan adanya moralitas, berakal, dan professional dalam melakukan pekerjaanya sebagai bagian dari kehidupannya. Selanjutnya bertanggungjawab kepada masyarakat dapat diartikan seorang notaris

\footnotetext{
18 Somadiyono, S. (2017). Pelaksanaan Pemberian Bantuan Hukum di Bidang Kenotariatan Secara Cuma-Cuma Terhadap Orang Yang Tidak Mampu, Jurnal LEX SPECIALIS, (20), 99-112.
} 
bersedia memberi pelayanan dengan sebaik-baiknya, dengan tidak memberikan pelayanan yang berbeda terhadap klien yang mampu untuk membayar tinggi ataupun klien yang kurang mampu serta dapat memberikan pelayanan yang berkualitas, dan memberi dampak yang positif dan membantu masyarakat. Dalam memberikan pelayanan tersebut tidak hanya karena mencari suatu keuntungan namun dengan mengabdi kepada sesama manusia.

Sesuai dengan peraturan yang telah ditentukan pada Pasal 36 UUJN yaitu honorarium seorang notaris menentukan dimana seorang notaris memiliki hak untuk menerima honorarium untuk jasa hukum yang telah dilakukan sesuai dengan kewenangan yang dimiliki. Namun tidak hanya hak yang layak didapatkan oleh notaris dengan memberikan jasa hukum tersebut, notaris juga mempunyai kewajiban dalam memberi jasa hukumnya tersebut dengan sukarela (tanpa memungut honorarium) kepada masyarakat yang tidak memiliki kemampuan yang telah ditentukan pada Pasal 37 UUJN. Ketentuan ini diwajibkan kepada notaris sebagai bentuk tanggung jawab sosial kepada masyarakat, khususnya terhadap masyarakat yang tidak mampu dan sedang memerlukan jasa hukum dalam hal pembuatan fakta oleh Notaris. Pada dunia hukum khususnya kenotariatan dikenal dengan adanya sanksi administratif, yang dimana diakui pula dalam UndangUndang Perubahan Atas UUJN, yaitu apabila notaris melakukan sebuah pelanggaran maka tidak saja dapat diberikan sanksi secara perdata namun dapat juga dikenakan sanksi secara administrasi. Sanksi dalam administrasi negara memiliki pengertian sebagai bentuk atau alat kekuasasaan yang memiliki sifat hukum publik, dan oleh pemerintah bisa menjadi bentuk tanggapan atau reaksi atas tidak patuhnya dengan kewajiban-kewajiban yang telah diatur dalam ketentuan hukum administrasi negara. Dapat dilihat sanksi administratif mencakup:

1. Adanya tuntutan atau desakan dari pemerintah (besturssdwang), yaitu Merupakan reaksi-reaksi secara nyata dari pemerintah yang memiliki tujuan untuk menyelesaikan keadaan-keadaan yang tidak diperbolehkan oleh tatanan hukum admnistrasi.

2. Adanya suatu penarikan kembali terhadap ketetapan yang memiliki keuntungan seperti, izin, pembayaran, dan subsidi. Dalam hal ini penerapan sanksi yang didasarkan pada penarikan kembali atau dapat dikatakan sudah tidak berlaku lagi suatu keputusan yang dulu, sehingga selanjutnya akan mengeluarkan suatu keputusan yang baru.

3. Dikenakanannya denda administratif, hal ini dapat ditujukan bagi para pihak yang berbuat pelanggaran terhadap setiap orang yang telah melakukan pelanggaran terhadap undang-undang, dan akan dikenakan dengan biaya selaras sesuai dengan aturan yang ada.

4. Pemerintah akan mengenakan uang paksa, yang bertujuan agar memberi hukuman secara pasti, selain dengan dikenakannya denda sesuai dengan ketentuan yang berlaku.

Penetapan Sanksi Administrasi ini sangat baik diterapkan bagi notaris, karena hal tersebut dapat memberi peringatan apabila melakukan pelanggaran-pelanggaran yang telah ditetapkan dalam UUJN, maupun ketentuan peraturan yang telah diautur pada Kode Etik Notaris. Pada ketentuan sanksi pelanggaran notaris terhadap Pasal 37 ayat (1) UUJN selanjutnya ditentukan dalam Pasal 37 ayat (2) UUJN dengan sifat berjenjang sesuai dengan tingkat kesalahan dari notaris yang melangar tersebut, yaitu :

1. Peringatan secara lisan 
2. Peringatan secara tertulis

3. Pemberhentian sementara

4. Pemberhentian dengan hormat,

5. Pemberhentian secara tidak hormat.

Pencantuman sanksi baik secara memberi peringatan dengan lisan ataupun dengan memberikan peringatan secara tertulis merupakan bentuk permulaan penjatuhan sanksi dan sanksi selanjutnya tidak tergolong sanksi administratf. Sanksi administratif menurut Philipus M. Hadjon "Dalam sanksi administratif berupa paksaan pemerintah, sebelum dijatuhkan sanksi harus didahului dengan adanya peringatan lisan dan peringatan tertulis, hal ini dimasukkan sebagai aspek prosedur paksaan nyata". 19

Pada prosedur dalam memberikan sanksi administratif yang diterapkan secara langsung bagi instansi-instansi yang mempunyai wewenang dalam memberikan sanksi administratif itu, merupakan suatu bentuk upaya secara preventif atau melakukan pengawaasan yang dilakukan dengan pemeriksaan terhadap protokol notaris dengan cara bertahap dengan mengecek adanya kemungkinan pelanggaran dalam melaksanakan jabatannya sebagai notaris. Selanjutnya dengan langkah secara represif yaitu dalam menerapkan sanksi, yang dalam memberikan sanksi itu dilaksanakan oleh Majelis Pengawas Wilayah (MPW), penjatuhan sanksi yang dilakukan dengan memberikan teguran baik teguran lisan maupun teguran tertulis yang mencakup hak dalam memberikan suatu usulan kepada Majelis Pengawas Pusat untuk menjatuhkan hukuman dengan pemberhentian dengan sementara dengan kurun waktu tiga (3) bulan hingga enam (6) bulan lamanya. Untuk selanjutnya Majelis Pengawas Pusat akan memberikan hukuman dengan pemberhentian secara sementara terhadap notaris tersebut dan mempunyai hak untuk memberi usulan kepada Mentri untuk menjatuhkan sanksi seperti memberhentikan notaris tersebut secara tidak hormat, dan bila bentuk pelanggaran yang diperbuat notaris tersebut sangat berat. Sanksi secara administratif pertanggungjawaban notaris, bahwa seorang notaris dapat dikenakan sanksi administrasi berupa pemberhentian sementara, pemberhentian dengan hormat atau pemberhentian dengan tidak hormat terhadap notaris yang melakukan perbuatan melawan hukum.

Pada sanksi pemberhentian sementara dari jabatan notaris atau dapat disebut skorsing adalah sebagai bentuk waktu menunggu pelaksanaan sanksi paksaan dari pemerintah. Sanksi pemberhentian sementara dari jabatan notaris dimaksudkan supaya notaris tersebut untuk tidak melaksanakan tugas serta jabatannya sementara waktu, sebelum dikenakannya sanksi berupa pemberhentian dengan hormat dan/atau pemberhentian secara tidak hormat. Dapat dilihat seiring berjalannya waktu, kehidupan masyarakat semakin maju dan kebutuhan masayarakat dalam diberikannya suatu perlindungan hukum juga ikut meningkat, hal inilah yang membuat kebutuhan akan jasa notaris dalam memberikan pelayanan dalam bidang hukum sangat diperlukan juga dalam hal perekonomian negara yang diharapkan semakin membaik untuk masyarakat. Faktor ini lah yang memunculkan adanya

${ }_{19}$ Hadjon, Philipus M., et.all., (2002), Pengantar Hukum Administrasi Negara Indonesia, Yuridika, Surabaya, h. 23 
salah satu kewajiban notaris dalam memberikan pelayanan hukum bagi masyarakat yang tidak mampu.

Adapun akibat hukum bagi seorang notaris yang keberatan dan tidak mau dalam memberi jasa hukum terhadap masyarakat yang tidak mampu berdasarkan ketentuan Pasal 85 UUJN dapat dikenakan sanksi berupa :
1. Teguran Lisan;
2. Terguran tertulis
3. Pemberhentian sementara;
4. Pemberhentian dengan hormat; atau
5. Pemberhentian secara tidak hormat.

Untuk ketentuan yang ditentukan dalam Pasal 84 UUJN tidak memberikan pengaturan tentang sanksi bagi penolakan notaris yang enggan memberi bantuan hukum dengan cuma-cuma atau secara sukarela bagi masyarakat, sehingga bila adanya pelanggaran, tidak sampai dijatuhi sanksi secara pidana. Dengan demikian untuk memberikan bantuan hukum dengan sukarela bagi masyarakat tetap dilakukan berdasarkan kesepakatan para pihak antara pemohon bantuan hukum dengan notaris dengan berdasarkan peraturan Pasal 1338 ayat (1) KUHPerdata. Selain ketentuan pada UUJN, dalam ketentuan pada Kode Etik Notaris turut menentukan tentang sanksinya dan tertuang pada Pasal 6 ayat 1 Kode Etik Notaris, adapun sanksi yang telah ditentukan atas pelanggaran Kode Etik yaitu seperti:

1. Memberi teguran;

2. Memberikan peringatan;

3. Akan dilakukan pemberhentian secara sementara dari keanggotaan Perkumpulan;

4. Akan dilakukan pemberhentian dengan hormat dari keanggotaan Perkumpulan;

5. Diberhentikan secara tidak hormat dari keanggotaan Perkumpulan.

Peraturan mengenai sanksi tersebut dalam penjatuhannya untuk anggota notaris yang telah melanggar ketentuan peraturan, dengan menyesuaikan sebarapa berat pelanggaran yang telah diperbuat. Dapat dijelaskan sanksi merupakan suatu hukuman yang ditujukan sebagai salah satu sarana atau bentuk paksaan terhadap menaati dan disiplin sebagai anggota perkumpulan ataupun sebagai anggota notaris untuk menegakkan kode etik notaris didalam perkumpulan. Untuk menjatuhkan sanksi terhadap anggota atau notaris yang melanggar peraturan dilakukan oleh Dewan Kehormatan yang memiliki wewenang dalam memeriksa anggota yang melakukan pelanggaran, dan juga dalam menjatuhkan sanksi sesuai dengan kewenangan dan tindakan apa yang dilanggar oleh anggotanya. Dalam hal ini Dewan Kehormatan memiliki peran sebagai alat perlengkapan perkumpulan dan sebagai suatubadan atau lembaga secara independen juga tidak memihak didalam perkumpulan, tugas bagi Dewan Kehormatan yaitu:

1. Menjalankan pembinaan, memberikan bimbingan, melakukan pengawasan, serta melakukan pembenahan terhadap anggota untuk dapat mentaati Kode Etik. 
2. Dewan Kehormatan memiliki tugas dalam memeriksa dan mengambil keputusan atas dugaan pelanggaran ketentuan kode etik yang dilakukan notaris dan bersifat internal atau yang tidak mempunyai kaitan dengan kepentingan masyarakat secara langsung.

3. Memberi saran dan pendapat kepada Majelis Pengawas atas dugaan pelanggaran kode etik dan jabatan Notaris yang dilakukan oleh notaris yang melanggar. Dewan Kehormatan juga bertugas dalam mengawasi juga dalam memberikan suatu keputusan bagi pelanggaran ketentuan dalam kode etik secara internal maupun tidak berhubungan kepada kepentingan rakyat secara langsung, berdasarkan peraturan dalam Pasal 1 ayat 8 bagian a Kode Etik Notaris. 20

Pada saat memeriksa dan menjatuhkan sanksi yang dilakukan Dewan Kehormatan Wilayah juga dalam menentukan apakah terbukti melakukan kesalahan dan seberapa berat pelanggaran yang dilakukan, setelah dari itu akan mendengar segala penjelasan dan pembelaan diri yang dilakukan oleh notaris yang melanggar ketentuan. Selanjutnya apabila pada putusan sidang Dewan Kehormatan Daerah melihat memang ada kesalahan maka akan langsung ditentukan jenis sanksi apa yang akan dikenakan kepada notaris yang melanggar ketentuan. Untuk jenis sanksi teguran dan memberi peringatan tidak memerlukan perundingan dengan pengurus daerah, namun bila dikenakan sanksi yaitu akan diberhentikan secara sementara, maupun dengan cara pemberhentian dari keanggotaan maka harus diadakan rapat atau persidangan dengan pengurus perkumpulan lainnya. Pada penerapan sanksi dengan memberhentikan notaris tersebut secara sementara juga memberhentikan notaris secara tidak hormat sebagai anggota perkumpulan wajib adanya pemberitahuan kepada Majelis Pengawas Daerah (MPD), langkah selanjutnya akan dilakukan pemberitahuan kepada Menteri Hukum dan Hak Asasi Manusia. Pemberhentian ini bukan pemberhentian dari jabatannya sebagai notaris, melainkan pemberhentian dari keanggoataannya yaitu dari anggota Ikatan Notaris Indonesia (I.N.I).

Bila dilihat dalam prakteknya dalam ranah pelanggaran bagi seorang notaris yang enggan memberikan jasa dengan sukarela kepada orang yang tidak memiliki kemampuan, tidak sampai kepada penerapan sanksi dengan pemberhentian sebagai anggota notaris, melainkan hanya sebatas teguran secara lisan maupun tertulis. Pengaturan terkait pihak mana yang dapat dianggap atau digolongkan sebagai orang yang tidak mampu juga belum ada pengaturannya. Apabila melakukan pelanggaran, notaris tersebut tidak hanya terkena sanksi dari segi hukum positifnya saja melainkan juga mendapat sanksi moral dari masyarakat yaitu seperti halnya masyarakat tidak mau datang kembali ke notaris tersebut, masyarakat menjadi tidak percaya lagi terhadap notaris tersebut karena dianggap tidak mempunyai nilai moral sebagai pejabat umum yang berwenang dan berkewajiban demi membantu sesama dapat juga sanksi secara spiritual, dimana bisa saja notaris tersebut kurang mendapatkan kesejahteraan dalam hidupnya. Penerapan sanksi-sanksi tersebut baik menurut UUJN, Kode Etik maupun berupa sanksi moral dari masyarakat sangatlah penting dalam mewujudkan

${ }^{20}$ Siska Harun Bukoh, Op .cit, h. 4 
profesionalisme seorang notaris. Terutama dalam kepentingan dan kebutuhan masyarakat yang kurang mampu dalam pembuatan akta dimaksudkan dapat memberi suatu perlindungan hukum bagi masyarakat begitupula untuk dapat mewujudkan profesionalisme seorang notaris. Pada penjatuhan sanksi bagi Notaris juga dapat diartikan sebagai pejabat umum, notaris memiliki wewenang untuk dapat membuat akta otentik juga mempunyai suatu kewajiban moral dalam membantu masyarakat tidak mampu yaitu dalam memberikan jasa hukumnya kepada mereka yang membutuhkan tanpa memungut biaya atau honorarium atas jasanya.

\section{Kesimpulan}

Penerapan dalam memberikan bantuan hukum oleh seornag notaris dalam bidang hukum peradata khususnya kenotariatan dengan sukarela terhadap orang yang tidak mampu dilakukan berdasarkan dengan pada Pasal 37 ayat (1) UUJN, yakni seorang pejabat umum yaitu notaris dalam melakukan pekerjaannya dengan membuat akta autentik tanpa memungut honorarium tidak saja diberikan terhadap masyarakat yang tidak mampu saja, tetapi notaris bisa memberikan jasa secara sukarela kepada para pihak ingin mendirikan yayasan atau kegiatan-kegiatan dibidang sosial, kemanusiaan dan keagamaan. Adapun akibat hukum untuk notaris yang enggan dalam memberi jasa hukum khususnya hukum perdata dan kenotariatan bagi masyarakat yang tidak memiliki kemampuan lebih dalam ekonomi yaitu berupa teguran secara lisan, terguran secara tertulis, memberhentikan notaris secara sementara, memberhentikan notaris dengan hormat, ataupun memberhentikannya dengan tidak hormat, sanksi tersebut juga seperti sanksi yang telah ditentukan dalam Kode Etik I.N.I yaitu berupa, teguran terhadap notaris bersangkutan, memberi peringatan secara tertulis maupun lisan, melakukan pemberhentian notaris secara sementara dari keanggotaan Perkumpulan, Pemberhentiann dengan hormat dari keanggotaan Perkumpulan, memberhentikannya secara tidak hormat dari keangggotaan Perkumpulan.

\section{Daftar Pustaka}

\section{$\underline{\text { Buku }}$}

Abdul Ghofur Anshori. 2009. Lembaga Kenotariatan Indonesia (Perspektif Hukum dan Etika). UII Press. Yogyakarta.

Hadjon, Philipus M., et.all. 2002. Pengantar Hukum Administrasi Negara Indonesia. Yuridika. Surabaya.

Ignatius Ridwan Widyadharma. 2009. Kenotariatan Indonesia. UIIPress. Yogyakarta.

Soerjono Soekanto. 2014. Pengantar Penelitian Hukum. cetakan Ketiga. UI Press. Jakarta.

\section{Jurnal}

Buko, S. H. (2017). Analisis Yuridis Tentang Kewajiban Notaris Dalam Memberikan Jasanya Kepada Masyarakat Yang Tidak Mampu Berdasarkan UU No. 2 Tahun 2014. Lex Privatum. 
Diana, P. V. P., Mertha, I. K., \& Artha, I. G. (2015). Pertanggung Jawaban Notaris Dalam Pembuatan Akta Berdasarkan Pemalsuan Surat Oleh Para Pihak. Acta Comitas: Jurnal Hukum Kenotariatan. 161-172.

Dirgantara, P. Tanggung Jawab Saksi Pengenal Terhadap Keterangan yang Diberikan dalam Pembuatan Akta Autentik. Acta Comitas: Jurnal Hukum Kenotariatan, 4(2), 187-197.

Gitayani, L. P. C. (2018). Penerapan Etika Profesi oleh Notaris dalam Memberikan Pelayanan Jasa Kepada Klien. Acta Comitas: Jurnal Hukum Kenotariatan, 3(3), 426435

Gultom, R. (2017). Penetapan Honorarium Atas Jasa Hukum Notaris. Jurnal. Universitas Hasanuddin.

Kurniawan, I. W. A. (2018). Tanggung Jawab Notaris Atas Akta yang Tidak Dibacakan Dihadapan Para Penghadap. Acta Comitas: Jurnal Hukum Kenotariatan, 3(3), 489499.

Laurensius Arliman, S. (2013). Kewajiban Notaris Dalam Pemberian Penyuluhan Hukum Kepada Masyarakat Berdasarkan Undang-Undang Nomor 2 Tahun 2014 Tentang Perubahan Atas Undang-Undang Nomor 30 Tahun 2004 Tentang Jabatan Notaris. Jurnal Advokasi.

Purwaningsih, E. (2011). Penegakan Hukum Jabatan Notaris dalam Pembuatan Perjanjian Berdasarkan Pancasila dalam Rangka Kepastian Hukum. Adil: Jurnal Hukum.

Sari, D. A. P. (2016). Makna Pemberian Jasa Hukum Secara Cuma-cuma Oleh Notaris Pada Orang Tidak Mampu Terkait Sanksi Yang Diberikan Oleh Undang-undang Jika Tidak Dipenuhi (Analisis Pasal 37 Ayat (1) Dan (2) Undang-undang Jabatan Notaris No. 2 Tahun 2014). Kumpulan Jurnal Mahasiswa Fakultas Hukum.

SN, H. R. (2017). Pelaksanaan Pelayanan Jasa Notaris Terhadap Orang Tidak Mampu. Keadilan Progresif.

Somadiyono, S. (2017). Pelaksanaan Pemberian Bantuan Hukum di Bidang Kenotariatan Secara Cuma-Cuma Terhadap Orang yang Tidak Mampu. Jurnal Lex Specialis.

\section{Internet}

Dwi Suryahartati, Peran Perguruan Tinggi Dalam Praktik Terkini Profesi Notaris yang Lihur dan Bermartabat, http://webunja.unja.ac.id/artikel/88-peranan-perguruantinggi-dalam- praktik-terkini-profesi-notaris-yang-luhur-dan- bermartabat, Diakses pada tanggal 17 Januari 2020.

\section{$\underline{\text { Peraturan Perundang-Undangan }}$}

Kitab Undang-Undang Hukum Perdata (Burgerlijk Wetboek). 
Undang-Undang Republik Indonesia Nomor 2 Tahun 2014 tentang Perubahan Atas Undang-Undang Nomor 30 Tahun 2004 Tentang Jabatan Notaris, Lembaran Negara Republik Indonesia Tahun 2014 Nomor 293, Tambahan Lembaran Negara Republik Indonesia Nomor 5602.

Kode Etik Notaris. 